\section{AMID THE HIGH CAIRNGORMS}

The Cairngorms on Foot and Ski

By V. A. Firsoff. Pp. $279+49$ plates. (London: Robert Hale, Ltd., 1949.) 15s. net.

$\mathrm{HE}$ range of the Cairngorms is in the opinion of many people the finest mountain land in Britain. Mr. V. A. Firsoff in this book has written of his experiences of this hill range. He describes how he saw them first during the grim years of the Second World War, and since that day he has climbed and photographed them not only in summer, but also in winter when, like the Norwegian troops stationed in the district during the War, he has roamed their high plateaux on skis in all weathers, sometimes battling with blizzards so fierce that life itself seems precarious. The illustrations which he has taken with his camera show that he has an eye to a good picture; some of them are excellent. He writes clearly and graphically, and we follow him on his climbs from the Linn of Dee and from Achlean in Glen Feshie, from which hospitable house he first made the acquaintance of the Cairngorms in the war years.

Mr. Firsoff has a good deal to say about the ancient forests of Scots fir and their ruthless felling, not only during the War but also afterwards. I am glad that he directs attention to the danger that we may lose entirely these fine woods. This can be prevented, on the south slopes of the Cairngorms at all events, by fencing in areas against deer and allowing the seedlings to make a start. I have repeatedly urged this, yet nothing has been done; as it is, each seedling is eaten, and in Mar Forest there is not a single young tree to be seen. Mr. Firsoff writes of the recently formed National Park in Glen More, and the possibility of the whole range becoming a larger national park.

In his botanical chapter the author makakes some surprising statements, as, for example, when (p. 46) he writes: "In Coire Beanaidh along the scarp of Sron na Lairig I came across carpets of purple saxifrage in livid bud, on the point of opening". I have known the Cairngorms for the best part of forty-five years but have yet to find, nor do I know any botanist who has found, this schist-loving saxifrage on the high tops or in the high corries of the Cairngorms, where the granite formation is distasteful to it. Nor (p. 48) have I found the blaeberry (Vaccinium myrtillus) abundant at the Wells of Dee where I have spent, at one time or another, a considerable number of days. The mossy cyphel has not been recorded from the Cairngorm area and not nearer than seventy miles from it. Azalea procumbens flowers earlier, and not later, than Silene acaulis, unless it has been kept back, as it sometimes is, by extensive snow fields remaining until late spring on its flowering slopes.

I am perplexed, too, by the author's Camberwell Beauty butterfly (p. 19), which he saw in winter in Glen Feshie. This butterfy is a rare vagrant and is seen mostly on the east coast. To have seen it in February in Glen Feshie surely merits more than a passing casual remark. There was never (p. 74) a colony of black-headed gulls on Loch nan Stuirteag.

On p. 88 he talks of seeing the Cuillin Hills of Skye from the Cairngorms, but he has confused them with the Sisters of Kintail. There is, it is true, a tradition in Rothiemurchus that the Cuillin are visible, but the shape of those distant pointed hills is not the shape of the Cuillin. I consulted the Ordnance Survey on this question, and they were good enough to interest themselves in the matter and informed me that, because of an intervening hill sixty miles distant, the Cuillin are invisible from the Cairngorms.

The book is excellently produced. In a second edition, which is sure to follow, the errors Uisga for Uisge (p. 14), statistickal for statistical on p. 36, and on p. 30 the English translation of Moine Bhealaidh will doubtless be rectified. SETON GordoN

\section{IN PRAISE OF EPPING FOREST}

\section{London's Epping Forest}

By James A. Brimble. Pp. 176. (London: Country Life, Ltd., 1950.) 30s, net.

$\mathrm{W}$

HEN you pick up this handsome book, you find yourself either immediately interested in Epping Forest ("It is little more than half an hour from Town. . . And oh ! so near to London !") or fascinated by the superb photographs.

Epping Forest is a comparatively large natural area stretching from the north-eastern edge of urban Greater London deep into the heart of rural, agricultural Essex. Part is actual forest; but other parts are suburban in character and there are some small areas of common, copse and verge. (Mr. Brimble deals only with a section of the forest.) It is a forest with a history, too. One needs only to mention such as the ancient British camps of Ambersbury Banks and Loughton, Waltham Abbey and Hainault to remind the reader that here was where much of Britain's history was enacted. Also as a forest, this area has for centuries played an important part. The Normans used the area for hunting. Deforestation occurred under the weak regimes of John and Edward I.; but afforestation was the order of the day under nearly all the Henries. Then the area was the scene of many a royal hunt - the Norman kings, the Plantagenets, the Tudors and the Stuarts-reaching its peak with Henry VIII ; but the hunts ceased after Charles II. The forestry programme of the area has suffered many vicissitudes, and even Parliament has not been guiltless of making easy money from the sale of timber that this area afforded; that is how the part known as Hainault Forest disappeared so recently as 1851. Finally in 1878 , by an Act of Parliament, six thousand acres, now called Epping Forest, were placed under the administration of the Corporation of the City of London. Such is the position to-day.

We are told this, and much more besides, by the author, who then proceeds, in fifteen engaging chapters, to describe the Forest of to-day.

There is animal life, too. Domesticated cattle and horses from adjoining farms graze on the lawns (or Forest plains as they are called); the well-known deer number about two thousand. Some foxes are allowed, and almost invariably badgers eventually take over the formers' earths and enlarge them for themselves. Also, alas, the immigrant grey squirrel is now becoming a pest there.

The text abounds with descriptions which will appeal to all natural historians, for it is written by a man who has spent twenty-five years of his life on the edge of the Forest.

The most outstanding feature of the book, nevertheless, are the 115 photographs, all of which have been taken by the author. He is well known as a 